\title{
Farm Tractors in Kansas: How to Perfect a Security Interest
}

\author{
Aaron K. Johnstun ${ }^{*}$ \\ Stephen J. Ware ${ }^{* *}$
}

\section{INTRODUCTION}

Widespread enactment of the Uniform Commercial Code (UCC) occurred nearly half a century ago. ${ }^{1}$ Even so, significant nonuniformities in commercial law remain. One is the method of perfecting a security interest in a farm tractor.

As lawyers who have taken a secured transactions course will recall, a creditor maximizes its rights, not merely by getting a security interest, but by perfecting its security interest. Getting a security interest (attachment) in the debtor's property gives the creditor a lien in that property (the collateral). ${ }^{2}$ But the lien does not ensure that the creditor will be able to collect the value of that collateral if the debtor defaults. The creditor's lien may be subordinate to the rights of other parties with an interest in the collateral (such as another lienholder, ${ }^{3}$ a buyer of the collateral, ${ }^{4}$ or the debtor's trustee in bankruptcy ${ }^{5}$ ). To maximize its rights against these rivals, the creditor must perfect its security interest.

The method of perfecting a security interest varies with the type of collateral. With respect to most personal property, perfecting a security

\footnotetext{
* Redmond \& Nazar, L.L.P., Wichita, Kansas.

** Professor of Law, University of Kansas. For research assistance, thanks to Carrie Bader and Cheri Whiteside.

1. See 1 William D. Hawkland, Uniform Commercial Code Series § 1-101:1 (2001).

2. U.C.C. § 9-203 (2002).

3. Id. § 9-322(a)(1) ("Conflicting perfected security interests and agricultural liens rank according to priority in time of filing or perfection."); $i d$. § 9-317(a)(2)(A) (“A security interest or agricultural lien is subordinate to the rights of: ... a person that becomes a lien creditor before the earlier of the time the security interest or agricultural lien is perfected.").

4. Id. § 9-317(b) ("[A] buyer, other than a secured party, of tangible chattel paper, documents, goods, instruments, or a security certificate takes free of a security interest or agricultural lien if the buyer gives value and receives delivery of the collateral without knowledge of the security interest or agricultural lien and before it is perfected.").

5. 11 U.S.C. $\S \S 544-547$ (2006) (granting trustee in bankruptcy the powers of a lien creditor).
} 
interest is accomplished by filing a financing statement. ${ }^{6}$ And in most states that is how a creditor perfects its security interest in a farm tractor. Kansas statutes, however, indicate that to perfect a security interest in a farm tractor, filing a financing statement is ineffective. Kansas statutes require the owner of a farm tractor to obtain a nonhighway certificate of title and require lenders seeking to perfect security interests in farm tractors to do so by compliance with the certificate-of-title statute.

\section{A TYPiCAL StATE's LAW GOVERNING PERFECTION IN FARM TRACTORS}

As noted above, security interests in most personal property are perfected by filing a financing statement. ${ }^{7}$ But when the collateral is property subject to a certificate-of-title statute, a different rule applies. For example, in all fifty states, motor vehicles are subject to a certificateof-title statute. ${ }^{8}$ The UCC provides that security interests in such collateral are perfected not by filing a financing statement, but by compliance with the relevant certificate-of-title statute. The UCC does this in section 9-311, which states:

(a) Except as otherwise provided in subsection (d), the filing of a financing statement is not necessary or effective to perfect a security interest in property subject to:

(2) [list any certificate-of-title statute covering automobiles, trailers, mobile homes, boats, farm tractors, or the like, which provides for a security interest to be indicated on the certificate as a condition or result of perfection, and any non-Uniform Commercial Code central filing statute];

$\cdots$

(b) Compliance with the requirements of a statute, regulation, or treaty described in subsection (a) for obtaining priority over the rights of a lien creditor is equivalent to the filing of a financing statement under this article. Except as otherwise provided in subsection (d) and Sections 9-313 and 9-316(d) and (e) for goods covered by a certificate of title, a security interest in property subject to a statute, regulation,

6. U.C.C. §9-310(a).

7. Id.

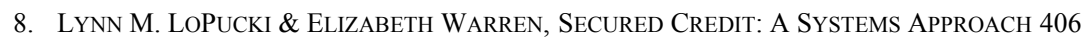
(5th ed. 2006). 
or treaty described in subsection (a) may be perfected only by compliance with those requirements, and a security interest so perfected remains perfected notwithstanding a change in the use or transfer of possession of the collateral.

Many states have read the bracketed language in section 9-311(a)(2) as an invitation to list specific certificate-of-title statutes. For example, Missouri's version of section 9-311(a)(2) states:

(1) [T] he filing of a financing statement is not necessary or effective to perfect a security interest in property subject to:

$\cdots$

(2) Sections 301.600 to 301.661 , RSMo and section $400.2 \mathrm{~A}-304 .^{10}$

Section 301.600 of the Missouri Code requires that a security interest in a motor vehicle be noted on the certificate of title. ${ }^{11}$ Accordingly, the filing of a financing statement is not necessary or effective to perfect a security interest in a Missouri motor vehicle. By contrast, notation of the security interest on the certificate of title is necessary and effective to perfect such a security interest.

While the UCC's section 9-311(a)(2) invites states to "list any certificate-of-title statute covering automobiles, trailers, mobile homes, boats, farm tractors, or the like," not all states have listed statutes covering all those types of collateral. For example, Missouri's list of statutes does not include a statute covering farm tractors. ${ }^{12}$ Thus, filing a financing statement, rather than notation on the certificate of title, is the way to perfect a security interest in a Missouri farm tractor. ${ }^{13}$

9. U.C.C. § 9-311(a)-(b) (emphasis added).

10. MO. ANN. STAT. § 400.9-311(a) (West 2003).

11. See id. $\S 301.600(1)$ ("Unless excepted by section 301.650, a lien or encumbrance on a motor vehicle or trailer, as defined by section 301.010, is not valid against subsequent transferees or lienholders of the motor vehicle or trailer who took without knowledge of the lien or encumbrance unless the lien or encumbrance is perfected as provided in sections 301.600 to 301.660 ."); id. $\S$ 301.620 (requiring that "[i]f an owner creates a lien or encumbrance on a motor vehicle or trailer: (1) The owner shall immediately execute the application ... to name the lienholder on the certificate").

12. "Farm tractors" are expressly excluded from Missouri's definition of a "motor vehicle." See id. § 301.010(34) (defining "[m]otor vehicle" as "any self-propelled vehicle not operated exclusively upon tracks, except farm tractors").

13. See Madison-Hunnewell Bank v. Hurt, 903 S.W.2d 175, 176 (Mo. Ct. App. 1995) (security interest in farm tractor perfected by filing financing statement). This case was decided under a prior version of Article 9, but the relevant statutory language was the same. See Mo. REV. STAT. $§ 400.9-$ 302(3)(b) (Supp. 1993) (current version at Mo. ANN. STAT. § 400.9-311(a) (West 2007)) (“The filing of a financing statement otherwise required by this article is not necessary or effective to perfect a security interest in property subject to ... section 301.190 , RSMo, or section 306.400 , RSMo ....”); 
What has just been said of Missouri is true of most states. In the majority of states, a certificate-of-title statute governing farm tractors is not listed in that state's version of 9-311(a)(2). ${ }^{14}$ Therefore, in these states, filing a financing statement-rather than notation on the certificate of title-is the way to perfect a security interest in a farm tractor.

\section{KANSAS’S ATYPICAL LAW GOVERNING PERFECTION IN FARM TRACTORS}

Although in most states perfection in a farm tractor is accomplished by filing a financing statement, rather than notation on a certificate of title for the tractor, Kansas statutes indicate the contrary. In Kansas, the relevant statutes indicate that the filing of a financing statement is not necessary or effective to perfect a security interest in a farm tractor. Rather, Kansas requires notation on the certificate of title to perfect a security interest in a farm tractor.

While the bracketed language in UCC section 9-311(a)(2) is (as noted above) often read as an invitation to list certificate-of-title statutes, the Kansas Legislature apparently declined this invitation. Instead, the Kansas version of section 9-311(a)(2) simply copies-without the brackets - the relevant language of the UCC. The Kansas version of section 9-311, K.S.A. 84-9-311, states:

(a) [T] he filing of a financing statement is not necessary or effective to perfect a security interest in property subject to:

(2) any certificate-of-title law of this state covering automobiles, trailers, mobile homes, boats, farm tractors, or the like, which provides for a security interest to be indicated on the certificate as a condition or result of perfection.

$\cdots$

(b) Compliance with the requirements of a statute, regulation, or treaty described in subsection (a) for obtaining priority over the rights of a lien creditor is equivalent to the filing of a financing statement under

Mo. ANN. STAT. § 301.190(1) ("No certificate of registration of any motor vehicle or trailer, or number plate therefore, shall be issued by the director of revenue unless the applicant therefore shall make application for and be granted a certificate of ownership of such motor vehicle or trailer ....").

14. See Appendix (citing statutes in thirty-one states). 
this article. Except as otherwise provided in subsection (d) and K.S.A. 2007 Supp. 84-9-313 and 84-9-316(d) and (e) and amendments thereto for goods covered by a certificate of title, a security interest in property subject to a statute, regulation, or treaty described in subsection (a) may be perfected only by compliance with those requirements, and a security interest so perfected remains perfected notwithstanding a change in the use or transfer of possession of the collateral. ${ }^{15}$

Unlike Missouri and most other states, Kansas does not use section 9311(a)(2) to list particular certificate-of-title statutes. Instead, K.S.A. 849-311(a)(2) leaves to courts the task of determining which certificate-oftitle statutes are included within its broad language.

Kansas's general certificate-of-title statute, K.S.A. 8-135, is such a statute and it does cover farm tractors. Therefore, courts should require notation on the certificate of title to perfect a security interest in a Kansas farm tractor. Filing a financing statement is neither necessary nor effective.

To understand K.S.A. 8-135's application to farm tractors, one must begin with how Kansas's certificate-of-title statutes define "farm tractor." A "farm tractor" is an example of a "nonhighway vehicle," as these terms are defined by Kansas statutes. The definition of a "nonhighway vehicle" is:

Any motor vehicle which cannot be registered because it is not manufactured for the purpose of using the same on the highways of this state and is not provided with the equipment required by state statute for vehicles of such type which are used on the highways of this state. ${ }^{16}$

This describes a farm tractor. A "farm tractor" is a "motor vehicle" under the Kansas statutory definition. ${ }^{17}$ Also, a "farm tractor" is defined as an "implement of husbandry" 18 and "implement of husbandry" is defined as a "vehicle designed or adapted and used exclusively for agricultural operations . . . and only incidentally moved or operated upon the highways." 19 So a farm tractor apparently "cannot be registered because it is not manufactured for the purpose" of being used on the

15. KAN. StAT. AnN. § 84-9-311(a)-(b) (Supp. 2007).

16. Id. $\S 8-197(\mathrm{~b})(1)(\mathrm{A})$ (emphasis added).

17. Id. $\S 8$-126(f) (A "farm tractor" means: "every motor vehicle designed and used as a farm implement . . . consistent with the structural design of such power unit.").

18. Id. $\S 8-126(\mathrm{cc})$ ("'Implement of husbandry' means every vehicle designed or adapted and used exclusively for agricultural operations, including feedlots, and only incidentally moved or operated upon the highways. Such term shall include, but not be limited to: (1) A farm tractor[.]").

19. Id. 
highways. $^{20}$ Therefore, we conclude that a "farm tractor" is a "nonhighway vehicle."

Having established that a "farm tractor" is a "nonhighway vehicle," we turn to the law governing nonhighway vehicles. Importantly, K.S.A. 8-198 requires the purchaser of a nonhighway vehicle to "obtain a nonhighway certificate of title." ${ }^{\text {"1 }}$ The application for this nonhighway certificate shall be made "in the same manner and under the same conditions prescribed by K.S.A. 8-135," ${ }^{22}$ which is Kansas's general certificate-of-title statute. That general certificate-of-title statute, in turn, requires the application for the certificate of title to "state all liens or encumbrances thereon." ${ }^{23}$ In sum, the purchaser of a farm tractor is

20. We say a farm tractor apparently "cannot be registered" because K.S.A. 8-198(a) says "[a] nonhighway or salvage vehicle shall not be required to be registered in this state, as provided in K.S.A. 8-135, and amendments thereto ...." Id. § 8-198(a) (emphasis added). We do not know if a farm tractor could be registered in Kansas and are not aware of anyone who has ever tried to do this.

21. Id. $\S 8-198(\mathrm{~b})-(\mathrm{c})$.

22. Id. § 8-198(b)(1), (c).

23. Section 8-135(c) provides, in pertinent part:

(c) Certificate of title: No vehicle required to be registered shall be registered or any license plate or registration decal issued therefor, unless the applicant for registration shall present satisfactory evidence of ownership and apply for an original certificate of title for such vehicle. The following paragraphs of this subsection shall apply to the issuance of a certificate of title for a nonhighway vehicle, salvage vehicle or rebuilt salvage vehicle, as defined in K.S.A. 8-197, and amendments thereto, except to the extent such paragraphs are made inapplicable by or are inconsistent with K.S.A. 8-198, and amendments thereto, and to any electronic certificate of title, except to the extent such paragraphs are made inapplicable by or are inconsistent with K.S.A. 2007 Supp. 8-135d, and amendments thereto, or with rules and regulations adopted pursuant to K.S.A. 2007 Supp. 8-135d, and amendments thereto.

The provisions of paragraphs (1) through (14) shall apply to any certificate of title issued prior to January 1, 2003, which indicates that there is a lien or encumbrance on such vehicle.

(1) An application for certificate of title shall be made by the owner or the owner's agent upon a form furnished by the division and shall state all liens or encumbrances thereon, and such other information as the division may require.

Id. (emphasis added). The above-quoted language requires a statement of liens for certificates issued before and after January 1, 2003. For certificates issued before that date, the quoted language expressly provides as much in (c)(1) and the sentence immediately preceding it. For certificates issued on or after January 1, 2003, the quoted language requires a statement of lien in the italicized language stating that, "the following paragraphs of this subsection shall apply ... to any electronic certificate of title ...." Id. Section 8-135d provides:

(a) On and after January 1, 2003, when an assignment of title or manufacturer's statement of origin indicates that there is a lien or encumbrance on a vehicle or if a notice of security interest has been filed with the division, the division shall retain possession of such certificate of title electronically and shall create an electronic certificate of title. The provisions of article 1 of chapter 8 of the Kansas Statutes Annotated, and amendments thereto, shall apply to an electronic certificate of title, except as otherwise provided by statute or by rules and regulations adopted pursuant to subsection (b).

(b) The secretary of revenue is hereby authorized to adopt rules and regulations 
obligated by statute, K.S.A. 8-198, to obtain a nonhighway certificate of title stating all liens on that farm tractor. Therefore, K.S.A. 8-198 is-to use the words of K.S.A. 84-9-311-a "certificate-of-title law of this state covering ... farm tractors." Thus, according to K.S.A. 84-9-311, "the filing of a financing statement is not necessary or effective to perfect a security interest in property subject to" K.S.A. 8-198, such as a farm tractor. A court analyzing this issue should conclude that the effective method to perfect a security interest in a Kansas farm tractor is by compliance with the certificate-of-title statute, K.S.A. 8-135.

While this issue has not been addressed in a reported case involving a farm tractor, it has been addressed in a case involving another type of nonhighway vehicle, an all-terrain vehicle (ATV). ${ }^{24}$ That case, In re Ramsey, contains persuasive reasoning by United States Bankruptcy Judge Dale Somers:

Because 8-198(c) incorporates most of 8-135's certificate of title provisions, including those about noting liens on them, the Court is convinced that decisions concerning the perfection of liens under 8-135 also apply to the perfection of liens under 8-198. Under the predecessor to 84-9-311 of Revised Article 9, courts applying Kansas law declared that notation on the certificate of title as required by $8-135$ was the only way to perfect a security interest in a vehicle covered by that statute. This requirement ensures that potential buyers can rely on the titles to show them whether any liens they need to worry about exist. $^{25}$

Judge Somers's conclusion is solidly grounded in the Kansas certificateof-title statutes governing nonhighway vehicles. And his reasoning applies, not just to ATVs, but to all nonhighway vehicles, including farm tractors.

It is true that K.S.A. 8-198(a) exempts nonhighway vehicles from "registration." ${ }^{\prime 26}$ But registration and the issuance of a certificate of title are two separate legal events. K.S.A. 8-198(a) exempts nonhighway vehicles from registration, but K.S.A. 8-198(b) nevertheless requires

necessary to carry out the provisions of this section.

Id.

24. Ramsey v. Sunflower Bank, N.A. (In re Ramsey), No. 02-14044-7, 2004 WL 2187178, at *1 (Bankr. D. Kan. Apr. 12, 2004).

25. Id. at $* 4$ (citations omitted).

26. $§ 8-198$ (a) ("A nonhighway or salvage vehicle shall not be required to be registered in this state, as provided in K.S.A. 8-135, and amendments thereto, but nothing in this section shall be construed as abrogating, limiting or otherwise affecting the provisions of K.S.A. 8-142, and amendments thereto, which make it unlawful for any person to operate or knowingly permit the operation in this state of a vehicle required to be registered in this state."). 
certificates of title for them. ${ }^{27}$ Thus, nonhighway vehicles, while exempt from registration, are nevertheless subject to certificate-of-title requirements.

\section{CONCLUSION}

Kansas statutes require the owner of a farm tractor to obtain a nonhighway certificate of title and require lenders seeking to perfect security interests in farm tractors to do so by compliance with the certificate-of-title statute. The filing of a financing statement is not effective to perfect such a security interest. Kansas commercial practitioners should take note.

27. In re Ramsey, 2004 WL 2187178 , at *4 ("A nonhighway vehicle is not required to be registered, but a Kansas statute, 8-198(c), does require a person who buys one to apply for a certificate of title for it."). 


\section{APPENDIX}

The following states' versions of UCC $\S 9-311(a)(2)$ contain lists of certificate-of-title statutes but do not include on that list a statute covering farm tractors:

1. Alaska. See AlaSka STAT. $\S 45.29 .311$ (a) (2007) ("[T]he filing of a financing statement is not necessary or effective to perfect a security interest in property subject to . . . (2) AS $28.10 \ldots$..."); id. § 28.10.201(a) ("Except as otherwise provided in (b) of this section ...., every owner of a vehicle subject to registration in this state shall apply for a certificate of title under this chapter."); id. $\S 28.10 .011$ ("Every vehicle ... in the state shall be registered under this chapter except when the vehicle is . . (11) an implement of husbandry...."); ALASKA ADMIN. CODE tit. 13, § 40.010(20) (Supp. 2008) (““[I]mplement of husbandry” . . includes farm tractors."); see also Northern Commercial Co. v. Cobb, 778 P.2d 205, 206 (Alaska 1989) (security interest in tractor perfected by filing financing statement; decided under prior version of Article 9, but the relevant statutory language was the same. See ALASKA STAT. § 45.09.302(c)(2) (1989) (current version at § 45.29.311)).

2. Arizona. See Ariz. ReV. Stat. AnN. § 47-9311(A) (2005) ("[T]he filing of a financing statement is not necessary or effective to perfect a security interest in property subject to: ... (2) [a] statute of this state that provides for central filing of or that requires indication on a certificate of title of a security interest in the property, including title 28 , chapter 7 , article 4 , and that requires indication of the security interest on a certificate of title for a vehicle required to be titled and registered under $\S$ 28-2153 ...."); id. § 28-2153(D) ("This section does not apply to: (1) [a] farm tractor.").

3. Arkansas. See ARK. CODE ANN. § 4-9-311(a) (West 2004) ("[T]he filing of a financing statement is not necessary or effective to perfect a security interest in property subject to: ... (2) any other laws of this state which provide for central filing of security interests or which require indication on a certificate of title to property of such interest, including but not limited to $\S \S 27-14-801-27-14-807 \ldots .$. ); id. $\S 27-14-801$ ("No... lien or encumbrance or title retention instrument upon a vehicle, of a type subject to registration under the laws of this state . . . is valid... until the requirements of this subchapter have been complied with." (emphasis added)); id. § 27-14-703 ("Every motor vehicle... shall be subject to the provisions of this [registration] chapter except: . . . (4) [a]ny special mobile equipment as defined in $\S 27-14-211 \ldots .$. ); $i d$. $\S$ 27-14-211 (“'Special mobile equipment' means every vehicle not 
designed or used primarily for the transportation of persons or property and incidentally operated or moved over the highways, including farm tractors ....").

4. California. See CAL. COM. CODE $\S$ 9311(a) (West 2002) ("[T]he filing of a financing statement is not necessary or effective to perfect a security interest in property subject to any of the following: ... (2)(A) [t]he provisions of the Vehicle Code which require registration of a vehicle ...."); CAL. VEH. CODE $§ 36100$ (Deering 2000) ("Implements of husbandry which are only incidentally operated or moved over a highway and implements of husbandry listed in Section 36005 or 36015 are exempt from registration."); id. § 36015 (“"Implement of husbandry' includes any farm tractor.....”); see also Cent. Cal. Equip. Co. v. Dolk Tractor Co., 144 Cal. Rptr. 367, 368 (Cal. Ct. App. 1978) (security interest in harvester combine perfected by filing a financing statement).

5. Connecticut. See ConN. Gen. StAT. ANN. § 42a-9-311(a) (West Supp. 2008) ("[T]he filing of a financing statement is not necessary or effective to perfect a security interest in property subject to: ... (2) [a]ny certificate-of-title statute covering automobiles, trailers, mobile homes, boats, farm tractors or the like, which provides for a security interest to be indicated on the certificate as a condition or result of perfection, and any non-Uniform Commercial Code filing statute, including chapter 247, section 21-67a, section 49-5, chapter 282 and chapter $283 \ldots$...); id. $\S$ 14-166(a) ("The acquisition of a certificate of title shall not be required and the issuance of a certificate of title by the Commissioner of Motor Vehicles shall not be required for... (7) special mobile equipment....”); id. § 14-165(9) (“"Special mobile equipment' means a vehicle not designed for the transportation of persons or property upon a highway and only incidentally operated or moved over a highway, including, but not limited to, ... tractors other than truck tractors . ...").

6. Delaware. See DEL. CoDE ANN. tit. 6, § 9-311(a) (West 2006) (" $[\mathrm{T}]$ he filing of a financing statement is not necessary or effective to perfect a security interest in property subject to: ... (2) Subchapter II of Chapter 23 of Title 21, relating to the notation of liens and encumbrances on certificates of title for motor vehicles ....”); id. tit. 21, § 2301(a) ("The Department shall not register or renew the registration of any motor vehicle or truck tractor unless and until the owner thereof makes application for and is granted an official certificate of title for such vehicle ...."); id. tit. 21, § 101(35) ("Motor vehicle' includes every vehicle, as defined in this section, which is self-propelled, except farm tractors ....").

7. Georgia. See GA. CODE ANN. § 11-9-311(a) (West 2003) ("[T]he filing of a financing statement is not necessary or effective to perfect a 
security interest in property subject to:... (2) Chapter 3 of Title $40 \ldots$. .. ; id. § 40-3-4 (West 2008) ("No certificate of title shall be obtained for ... (7) [s]pecial mobile equipment ...."); id. § 40-1-1(59) ("“Special mobile equipment' means every vehicle not designed or used primarily for the transportation of persons or property and only incidentally operated or moved over a highway, including but not limited to: ... tractors other than truck tractors ....”); see also Deere \& Co. v. Miller-Godley Auction Co., 549 S.E.2d 762, 764 (Ga. Ct. App. 2001) (security interest in tractor perfected by filing financing statement).

8. Idaho. See IDAHO CODE ANN. § 28-9-311(a) (West 2006) ("[T]he filing of a financing statement is not necessary or effective to perfect a security interest in property subject to:... (2) Section 49-510, Idaho Code ...."); id. § 49-501 (“(1) The provisions of this chapter [including Section 49-510] shall apply to every vehicle required to be registered with the department in chapter 4, title 49, Idaho Code .... (4) [v]ehicles exempt from registration under the provisions of section 49-426, Idaho Code, are exempt from the titling requirements of this chapter ...."); id. $\S 49-426$ (West Supp. 2008) ("The provisions of this chapter with respect to operating fees shall not apply to: ... (2) [f]arm tractors ....").

9. Illinois. See 810 ILL. COMP. StAT. ANN. 5/9-311(a)(2) (West 2004) ("[T]he filing of a financing statement is not necessary or effective to perfect a security interest in property subject to: . . the Illinois Vehicle Code [625 ILCS 5/1-100 et seq.] . . .”); 625 ILL. COMP. STAT. ANN. 5/3-102 (West 2008) ("No certificate of title need be obtained for . . (7) [s]pecial mobile equipment...."); id. 5/1-191 (defining special mobile equipment as "[e]very vehicle not designed or used primarily for the transportation of persons or property and only incidentally operated or moved over a highway, including but not limited to ... tractors other than truck tractors").

10. Kentucky. See Ky. ReV. Stat. ANN. § 355.9-311(1) (West 2006) (" $[\mathrm{T}]$ he filing of a financing statement is not necessary or effective to perfect a security interest in property subject to ... (b) KRS Chapter 186A ...."); id. § 186A.070 ("Except as otherwise provided, the state resident owner of a vehicle as defined in KRS 186.010(8)(a) . . shall . . . apply for and obtain a certificate of title ....”); id. § 186.010(8)(a) ("“Vehicle' ... includes all agencies for the transportation of persons or property over or upon the public highways... excepting... farm tractors ....."); see also Laurel Explosives, Inc. v. First Nat'l Bank \& Trust Co. of Corbin, 801 S.W.2d 336, 337 (Ky. Ct. App. 1990) (security interest in tractor perfected by filing financing statement; decided under prior version of Article 9). 
11. Massachusetts. See MASS. GEN. LAWS. ANN. ch. 106, § 9-311(a)(2) (West 2007) ("[T]he filing of a financing statement is not necessary or effective to perfect a security interest in property subject to: . . chapter 90B or chapter 90D ....”); id. ch. 90D, § 2(a) (West Supp. 2008) ("No certificate of title need be obtained for... (6) [a]n implement of husbandry; (7) [s]pecial mobile equipment.”); id. § 1 (defining "[s]pecial mobile equipment" as "vehicles exempt from registration by the registrar under the provisions of section nine of chapter ninety"); id. ch. $90 \S 9$ ("A tractor, trailer or truck may be operated without such registration upon any way for a distance not exceeding one-half mile, if said tractor, trailer or truck is used exclusively for agricultural purposes ....”).

12. Michigan. See Mich. Comp. LAWS ANN. § 440.9311(1)(b)(i) (West Supp. 2008) ("[T] effective to perfect a security interest in property subject to ... Chapter II of the Michigan vehicle code, 1949 PA 300, MCL 257.201 to 257.259."); id. § 257.216(c) (West 2007) ("Every motor vehicle... when driven or moved upon a highway, is subject to the registration and certificate of title provisions of this act except... [a]n implement of husbandry."); id. § 257.21 (“"Implement of husbandry' means a vehicle which is either a farm tractor, a vehicle designed to be drawn by a farm tractor or an animal, a vehicle which directly harvests farm products, or a vehicle which directly applies fertilizer, spray, or seeds to a farm field.").

13. Minnesota. See MinN. StAT. AnN. § 336.9-311(a)(2) (West Supp. 2008) ("[T] he filing of a financing statement is not necessary or effective to perfect a security interest in property subject to: ... sections ... 168A.01 to 168A.31 ..."); id. $\S 168$ A.03 ("The registrar shall not issue a certificate of title for: ... (5) an implement of husbandry ....”); id. $\S$ 168A.01(8)(a) (West 2006) ("'Implement of husbandry' means every vehicle, including a farm tractor and farm wagon, designed or adapted exclusively for agricultural, horticultural, or livestock raising operations or for lifting or carrying an implement of husbandry and in either case not subject to registration if used upon the highways."); see also Greenbush State Bank v. Stephens, 463 N.W.2d 303, 304 (Minn. Ct. App. 1990) (security interest in tractor perfected by filing financing statement; decided under prior version of Article 9).

14. Mississippi. See MISS. CodE ANN. § 75-9-311(a)(2) (West 2004) ("[T]he filing of a financing statement is not necessary or effective to perfect a security interest in property subject to: . . Sections 63-21-1 through 63-21-77 ...."); id. § 63-21-11(1)(f) (West Supp. 2007) ("No certificate of title need be obtained for:... [a]n implement of husbandry ...."); id. § 63-21-5(d) (“'Implement of husbandry' means every vehicle designed and adapted exclusively for agricultural, 
horticultural or livestock raising operations or for lifting or carrying an implement of husbandry and in either case not subject to registration if used upon the highways."); see also Thorp Commercial Corp. v. Miss. Road Supply Co., 348 So. 2d 1016, 1017 (Miss. 1977) (security interest in tractor perfected by filing financing statement; decided under prior version of Article 9).

15. Missouri. See supra notes 10-13.

16. Montana. See MONT. CODE ANN. § 30-9A-311(1)(b) (2005) ("[T]he filing of a financing statement is not necessary or effective to perfect a security interest in property subject to:... the certificate of title provisions of Title 23 or $61 \ldots$..."); $i d$. $\S 61-3-201(2)(\mathrm{f})$ ("The following motor vehicles ... are exempt from the requirements of this part: . . an implement of husbandry...."); id. § 61-1-101(22) (“"Implement of husbandry' means a vehicle that is designed for agricultural purposes and exclusively used by the owner of the vehicle in the conduct of the owner's agricultural operations."); see also 1st Bank v. Winderl, 60 P.3d 998, 999 (Mont. 2002) (security interest in tractor perfected by filing "financial [sic] statements").

17. Nebraska. See NeB. REV. Stat. U.C.C. § 9-311(a)(2) (Supp. 2006) ("[T]he filing of a financing statement is not necessary or effective to perfect a security interest in property subject to: ... the following statutes of this state: (i) section 60-164 ... and (ii) section 37-1282 . .."); id. § 60-137(1) (Supp. 2007) ("The Motor Vehicle Certificate of Title Act [including 60-164] applies to all vehicles as defined in the act, except: (a) [f]arm trailers; (b) [1]ow-speed vehicles...."); see also Melcher v. Bank of Madison, 529 N.W.2d 814, 817 (Neb. Ct. App. 1995) (security interest in tractor perfected by filing financing statement; decided under prior version of Article 9), rev'd on other grounds, 539 N.W.2d 837 (Neb. 1995).

18. Nevada. See NEV. REv. Stat. AnN. § 104.9311(1)(b) (West Supp. 2008) ("[T] to perfect a security interest in property subject to: . . Chapter 105 of NRS, NRS 482.423 to 482.431 , inclusive, 488.1793 to 488.1827 , inclusive, and 489.501 to 489.581 , inclusive ...."); id. $\S 482.210(1)$ ("The provisions of this chapter requiring the registration of certain vehicles do not apply to: ... (b) implements of husbandry temporarily drawn, moved or otherwise propelled upon the highways."); id. $\S$ 484.071 (West 2005) (“'Implement of husbandry' means every vehicle designed and adapted exclusively for agricultural, horticultural or livestock-raising operations or for lifting or carrying an implement of husbandry and in either case not subject to registration if used upon the highways."). 
19. New Hampshire. See N.H. REV. Stat. AnN. § 382-A:9-311(a)(2) (2004) ("[T]he filing of a financing statement is not necessary or effective to perfect a security interest in property subject to: .. RSA 261 ...."); id. § 261:3(I) (Supp. 2007) ("No certificate of title need be obtained for: ... (f) [a]n implement of husbandry ...."); id. § 259:44 ("“Implement of husbandry' shall mean equipment designed, adapted, and used exclusively for agricultural, horticultural, forestry, or livestock operations, for which use on a public way is incidental to its intended function. 'Implement of husbandry' shall include a self-propelled custom harvester.").

20. New Mexico. See N.M. StAT. ANN. § 55-9-311(a)(2) (West 2003) ("[T] he filing of a financing statement is not necessary or effective to perfect a security interest in property subject to: ... the provisions of Chapter 66 NMSA 1978 ....”); id. § 66-3-1(A)(3) (West Supp. 2008) ("[E]very motor vehicle ... when driven or moved upon a highway is subject to the registration and certificate of title provisions of the Motor Vehicle Code except:... any implement of husbandry that is only incidentally operated or moved upon a highway ...."); id. § 66-1-4.9(A) (West 2003) (“" $[\mathrm{I}] \mathrm{mplement}$ of husbandry' means every vehicle that is designed for agricultural purposes and exclusively used by the owner in the conduct of agricultural operations ...."); see also Case Credit Corp. v. Portales Nat'l Bank, 966 P.2d 1172, 1173 (N.M. 1998) (security interest in tractor perfected by filing financing statement; decided under prior version of Article 9); State v. Richardson, 832 P.2d 801, 803 (N.M. Ct. App. 1992) (farm tractors exempt from Motor Vehicle Code's registration requirements).

21. North Carolina. See N.C. GEN. StAT. AnN. § 25-9-311(a)(2) (West 2003) ("[T]he filing of a financing statement is not necessary or effective to perfect a security interest in property subject to: ... [a] certificate-oftitle statute of this State covering automobiles or other goods that provides for a security interest to be indicated on the certificate as a condition to or result of perfection of the security interest, including G.S. 20-58 and G.S. 75A-41 ....”); id. § 20-58(a) (West 2006) (“[A] security interest in a vehicle of a type for which a certificate of title is required shall be perfected only as hereinafter provided."); id. § 20-51 (West Supp. 2007) ("The following shall be exempt from the requirement of registration and certificate of title: ... (3) [a]ny implement of husbandry, farm tractor... that was designed for use in work off the highway and which is operated on the highway for the purpose of going to and from such nonhighway projects... [and] (5) [f]arm tractors equipped with rubber tires ...."). 
22. North Dakota. See N.D. Cent. Code § 41-09-31(1)(b) (West 2008) (" $[T]$ he filing of a financing statement is not necessary or effective to perfect a security interest in property subject to: ... Section 35-01$05.1 \ldots$. .. ; id. $\S 35-01-05.1$ ("No security interest in a vehicle ... is valid... unless the security interest is clearly indicated upon the certificate of title to the vehicle.... The term 'vehicle' ... includes any vehicle for which a certificate of title is required under title 39 or other statutes of this state."); id. § 39-05-02.2(6) ("No certificate of title need be obtained for:... [i]mplements of husbandry."); id. § 39-01-01(28) ("“Implement of husbandry' means every vehicle designed and adapted exclusively for agricultural, horticultural, or livestock raising operations or for lifting or carrying an implement of husbandry and in either case not subject to registration if used upon the highway."); see also Benson County Coop. Credit Union v. Cent. Livestock Ass'n, 300 N.W.2d 236, 240 (N.D. 1980) (security interest in tractor perfected by filing financing statement; decided under prior version of Article 9).

23. Ohio. See OHIO ReV. CodE AnN. § 1309.311(A)(2) (West 2004) ("[T] he filing of a financing statement is not necessary or effective to perfect a security interest in property subject to: . . Chapters 1547. , 1548., 4505., 4519., and 5309. of the Revised Code . . ."); id. § 4505.03 (West Supp. 2008) ("No person ... shall . . . buy or otherwise acquire a motor vehicle without obtaining a certificate of title for it ..."); id. $\S$ 4505.01(A)(2) (West 2008) (“"Motor vehicle' includes manufactured homes, mobile homes, recreational vehicles, and trailers and semitrailers whose weight exceeds four thousand pounds."); see also In re Miller, 44 B.R. 716, 717-20 (Bankr. N.D. Ohio 1984) (security interest in tractor perfected by filing financing statement; decided under prior version of Article 9); Farmers State Bank \& Trust Co. v. Mikesell, 554 N.E.2d 900, 902 (Ohio Ct. App. 1988) (same).

24. Oklahoma. See OKLA. STAT. ANN. tit. 12A, § 1-9-311(a)(2) (West Supp. 2008) ("[T]he filing of a financing statement is not necessary or effective to perfect a security interest in property subject to: ... another statute of this state that provides for central filing of, or that requires indication on or delivery for indication on a certificate of title of, any security interest in the property as a condition or result of perfection, including, but not limited to, Section 1110 of Title 47 and Section 4013 of Title 63 of the Oklahoma Statutes ...."); id. tit. 47, § 1110 (West 2008) ("[A] security interest in a vehicle as to which a certificate of title may be properly issued by the Oklahoma Tax Commission shall be perfected only when a lien entry form, and the existing certificate of title... are delivered to the Tax Commission or to a motor license agent.... For the purposes of this section, the term 'vehicle' shall not 
include special mobilized machinery ....”); id. § 1102(26) ("'Special mobilized machinery' means special purpose machines or devices, either self-propelled or drawn as trailers or semi-trailers, which derive no revenue from the transportation of persons or property, whose use of the highway is only incidental, and whose useful revenue producing service is performed at destinations in an area away from the traveled surface of an established open highway."); id. § 1102(33) ("“Vehicle' does not include bicycles, trailers except travel trailers and rental trailers, or implements of husbandry.... All implements of husbandry used as conveyances shall be required to display the owner's driver's license number or license plate number ... on the rear of the implement ...."); id. $\S 1-125$ (West 2007) (Implement of Husbandry is defined as "[e]very device, whether it is self-propelled, designed and adapted so as to be used exclusively for agricultural, horticultural or livestock-raising operations or for lifting or carrying an implement of husbandry and, in either case, not subject to registration if operated upon the highways.").

25. Oregon. See OR. REV. StAT. ANN. § 79.0311(1)(b) (West Supp. 2008) (" $[\mathrm{T}]$ he filing of a financing statement is not necessary or effective to perfect a security interest in property subject to: . . ORS chapter 830 and the Oregon Vehicle Code ...."); id. § 803.030(4) ("Road rollers, farm tractors and traction engines are exempt from the requirements for title."); see also Wade Credit Corp. v. Borg-Warner Acceptance Corp., 732 P.2d 76, 79 (Or. Ct. App. 1987) (security interest in tractor perfected by filing financing statement; decided under prior version of Article 9).

26. Rhode Island. See R.I. GEN. LAws § 6A-9-311(a)(2) (West 2006) (" $[\mathrm{T}]$ he filing of a financing statement is not necessary or effective to perfect a security interest in property subject to: ... a statute of this State, which provides for a security interest to be indicated on the certificate as a condition or result of perfection, including chapter 3.1 of Title 31 and chapter 22.1 of Title 46..."); id. § 31-3.1-2(7) ("No certificate of title need be obtained for:... [s]pecial mobile equipment.”); id. § 31-1-9 (“"Mobile equipment' means every vehicle not designed or used primarily for the transportation of persons or property and only incidentally operated or moved over a highway, including but not limited to: . . . tractors other than truck tractors ....").

27. South Carolina. See S.C. CODE ANN. § 36-9-311(a)(2) (2003) ("[T]he filing of a financing statement is not necessary or effective to perfect a security interest in property subject to: . . Chapter 19 of Title 56 . . and Chapter 23 of Title 50 ...."); id. § 56-19-220(7) (2006) ("No certificate of title need be obtained for: ... [s]pecial mobile equipment not required to be registered and licensed in this State ...."); id. § 5619-10(31) (“'Special mobile equipment' means every vehicle not 
designed or used primarily for the transportation of persons or property and only incidentally operated or moved over a highway including, but not limited to: . . . tractors other than truck tractors ....").

28. Tennessee. See TENN. CODE ANN. § 47-9-311(a)(2)(A) (West 2002) (" $[\mathrm{T}]$ he filing of a financing statement is not necessary or effective to perfect a security interest in property subject to: . . . a certificate-of-title statute of this state, covering automobiles, trailers, mobile homes, vehicles or the like, which provides for a security interest to be indicated on the certificate as a condition or result of perfection, under Tennessee Code Annotated, Title 55, Chapter 3 . ..."); id. § 55-3-101(a)(3) (West Supp. 2008) ("Every motor vehicle ... when driven or moved upon a highway... shall be subject to the registration and certificate of title provisions of chapters 1-6 of this title, except: ... [a]ny implement of husbandry ...."); id. § 55-1-108 (West 2002) ("Implement of husbandry' means every vehicle which is designed for agricultural purposes and exclusively used by the owner thereof in the conduct of the owner's agricultural operations, but does not include any truck, trucktractor or farm truck whenever such vehicle is driven upon a highway of this state except as provided in $\S 55-3-101(\mathrm{a})(2) . ")$; see also Westside Equip. Co. v. Greene County Bank, No. 03A01-9307-CH-00245, 1994 WL 44414 (Tenn. Ct. App. Feb. 16, 1994) (security interest in tractor perfected by filing financing statement; decided under prior version of Article 9); State v. Thompson, No. 03C01-9703-CR-00105, 1998 WL 221052, at *6 n.8 (Tenn. Crim. App. May 6, 1998) ("[A] farm tractor is not required under current Tennessee law to be registered or titled.").

29. Utah. See UTAH CODE ANN. § 70A-9a-311(1)(b) (West 2004) (" $[\mathrm{T}]$ he filing of a financing statement is not necessary or effective to perfect a security interest in property subject to:... Section 41-1a$601 \ldots .$. ..); id. § 41-1a-504(1) ("Each vehicle operated in this state is subject to the titling provisions of this part except: special mobile equipment ....”); id. § 41-1a-102(57)(b) ("“Special mobile equipment' includes: (i) farm tractors ....").

30. West Virginia. See W. VA. CODE ANN. § 46-9-311(a)(2) (West 2002) ("[T]he filing of a financing statement is not necessary or effective to perfect a security interest in property subject to: ... [t]he following statute of this state: Chapter seventeen-a of this code: . ..."); id. § 17A3-2(a) (West Supp. 2008) ("Every motor vehicle... when driven or moved upon a highway is subject to the registration and certificate of title provisions of this chapter except:... (2) [a]ny implement of husbandry upon which is used exclusively for agricultural or horticultural purposes on lands owned or leased by the owner of the implement and which is not operated on or over any public highway of 
this state for any other purpose other than for the purpose of operating it across a highway or along a highway other than an expressway ... from one point of the owner's land to another part of the owner's land.... (A) The exemptions contained in this section also apply to farm machinery and tractors: [p]rovided, [t] hat the machinery and tractors may use the highways in going from one tract of land to another tract of land regardless of whether the land is owned by the same or different persons ....").

31. Wisconsin. See Wisc. STAT. AnN. § 409.311(1)(b) (West 2003) ("[T]he filing of a financing statement is not necessary or effective to perfect a security interest in property subject to:... [t] the following vehicle title statutes: ss. 342.19 and $342.20 \ldots$...); id. $\S 342.19$ (West 2005) ("[A] security interest in a vehicle of a type for which a certificate of title is required is not valid against creditors of the owner or subsequent transferees or secured parties of the vehicle unless perfected as provided in this chapter."); $i d$. $\S 342.05(1)$ ("The owner of a vehicle subject to registration in this state... shall make application for certificate of title for the vehicle...."); id. § 341.05(7) (West Supp. 2007) ("A vehicle, even though operated upon a highway of this state, is exempt from registration if ... [t]he vehicle is a farm tractor used exclusively in agricultural operations, including threshing, or used exclusively to provide power to drive other machinery, or to transport from job to job machinery driven by a farm tractor."); see also DeutzAllis Credit Corp. v. Ziegler, No. 89-0264, 1989 WL 112304, at*3 (Wis. Ct. App. July 11, 1989) (security interest in tractor perfected by filing financing statement; decided under prior version of Article 9). 